\title{
Disability Prevention Programs for Older People: Factors Associated with Medical and Nursing Care Costs
}

\author{
Program Pencegahan Disabilitas untuk Lanjut Usia: Faktor-faktor yang \\ Terkait dengan Biaya Medis dan Perawatan
}

\author{
Takaaki Ikeda*, Susumu Yanagawa**, Kenichi Murakami***, Toshiyuki Inoue*, Takamasa Tsurumi****
}

\begin{abstract}
*Tanpopo Support Clinic of Home Health Care, Musashino, Japan, **Tsubasa Home-visit Rehabilitation and Home Nursing Center, Mitaka, Japan, $* * *$ Tsubasa Rehabilitation Center, Chofu, Japan, $* * * *$ Shohan Medical University, Yokohama, Japan
\end{abstract}

DOI: http://dx.doi.org/10.21109/kesmas.v10i2.880

\begin{abstract}
This study aimed to clarify factors associated with medical and nursing care costs for older people living in community and to suggest an effective disability prevention programs. Total of participants in this study was 83 individuals ( 29 men and 54 women; mean age $81.2 \pm 6.3$ years old) on November $1^{\text {st }}-$ December $28^{\text {th }}, 2014$. This study compared the average medical and nursing care costs per month with national average for those aged $\geq 65$ years old. Logistic regression test was conducted to examine its association with medical and nursing care costs. Those who had outing activities $\geq 3$ times a week were approximately three times less likely to reduce medical and nursing care costs than those who had outing activities $<3$ times a week despite three controlled covariates $(\mathrm{OR}=3.23$ and $95 \% \mathrm{Cl}=$ $1.03-10.42)$. Disability prevention programs that improve frequency of outing at least three times in a week may become a valid economic approach to older people who do not live in nursing home.

Keywords: Age treatment, disability prevention, frequency of outing, health economics and financing, health literacy

Abstrak

Penelitian ini bertujuan untuk mengklarifikasi faktor-faktor yang terkait dengan biaya medis dan perawatan lanjut usia (lansia) yang tinggal di panti sosial serta menyarankan program pencegahan disabilitas yang efektif. Total partisipan dalam penelitian ini adalah 83 orang (29 laki-laki dan 54 perempuan; usia rata-rata $81,2 \pm 6,3$ tahun) pada 1 November -28 Desember 2014. Penelitian ini membandingkan biaya medis dan perawatan rata-rata per bulan dengan rata-rata nasional bagi yang berusia $\geq 65$ tahun. Uji regresi logistik dilakukan untuk memeriksa keterkaitannya dengan biaya medis dan perawatan. Mereka yang pergi ke luar rumah $\geq 3$ kali seminggu tiga kali lebih kecil kemungkinannya untuk mengurangi biaya medis dan perawatan dibandingkan mereka yang pergi ke luar rumah $<3$ kali se-
\end{abstract}

minggu meskipun dengan tiga kovariat yang dikontrol (OR = 3,23 dan 95\% $\mathrm{Cl}=1,03-10,42$ ). Program pencegahan disabilitas yang meningkatkan frekuensi ke luar rumah sedikitnya tiga kali seminggu dapat menjadi pendekatan ekonomis yang valid pada lansia yang tidak tinggal di panti wreda. Kata kunci: Perawatan usia, pencegahan kecacatan, frekuensi pergi ke luar rumah, pembiayaan dan ekonomi kesehatan, literasi kesehatan

\section{Introduction}

Disability prevention programs that maximize effectiveness and minimize health costs for older people are major public health initiative worldwide. Cost utility analysis (CUA) is recommended to evaluate cost effectiveness in the field of health economics. ${ }^{1}$ Some studies have evaluated the cost effectiveness of disability prevention programs using CUA. According to studies published in 2013 - 2015 on PubMed, all intervention programs using a 'high risk' approach had poor cost effectiveness. ${ }^{2-6}$ As a result, not only 'high-risk' approaches but also 'population-based' approaches are increasing in clinical trials. From the disability prevention point of view, the 'high risk' approach is for individuals who are at risk of needing long-term clinical care. ${ }^{7}$ In contrast, the 'population-based' approach is aimed at changing the lifestyles of the wider population. ${ }^{7}$

In Japan, which has the highest proportion of older citizens, many intervention programs have been deve-

Correspondence: Takaaki Ikeda, Tanpopo Support Clinic of Home Health Care Musashino, Japan, 3-5-8, Kichijyoji-kita Machi, Musashino, Tokyo Japan,

Phone: +81-90-5587-3229, e-mail: t.ikeda0110@gmail.com 
loped in each municipality. According to a systematic review, many previous studies reported positive effects on the physical and psychological abilities for people enrolled in disability prevention programs. ${ }^{8}$ However, fewer studies have evaluated cost effectiveness using CUA for both 'high risk' and 'population-based' intervention programs. To our knowledge, some studies evaluated the cost effectiveness of both 'high-risk' and 'populationbased' disability prevention programs in older adults using cost benefit analysis. ${ }^{9,10}$ Those who participated in disability prevention programs that used both 'high risk' and 'population-based' approaches decreased their medical expenses while expenses steadily increased for those who did not participate in any disability prevention program. ${ }^{9,10}$ Moreover, in term of nursing care costs, both participating and non-participating groups experienced increasing nursing care costs, but the increase was much more moderate in the participating group. ${ }^{9}$ Therefore, these studies showed a possibility that disability prevention programs were cost-effective. However, more consideration is needed to reveal programs with the most valid approach focusing on disability prevention programs in older adults. Consequently, the aim of this study is to clarify factors associated with medical and nursing care costs for older people living in communities and to suggest an effective disability prevention program.

\section{Method}

As many as 90 Japanese individuals (aged over 65 years old) had enrolled in a disability prevention program on November $1^{\text {st }}-$ December $28^{\text {th }}, 2014$. This study excluded seven individuals who withdrew from the study. A total of 83 individuals ( 29 men and 54 women; mean age $81.2 \pm 6.3$ years old) participated in this study. They were enrolled on a fall prevention program and dementia prevention program by physiotherapists using a 'high risk' approach and a homebound prevention program using a 'population-based' approach. The homebound prevention program aimed to advance social participation by helping establish independent circles or to improve health literacy through online health-related lectures, leaflets and posters. This study compared the average medical and nursing care expenses (MNE) per month with the national average for those aged 65 years old and older as the outcome variable, with possible answers of 'less than 120 USD' and 'more than 120 USD'. 11

Based on results of previous studies, this study determined predictor variables that may correlate with MNE. ${ }^{2-15}$ The first was investigating basic characteristics, such as age, gender, educational attainment, chronic disease, number of family members living together and hospital attendance. The second was investigating the frequency of neighborhood outings as well as physical, psychological and cognitive abilities. Educational attainment was determined by years of formal education, with possible answers 'less than six years', 'six to less than nine years', '10 to less than 13 years', and 'more than 13 years'. Responses were divided into two groups namely 'less than 13 years' and 'more than 13 years.' Frequency of attending hospitals was ascertained by asking 'how often do you usually go to see a doctor?' with possible responses of 'once a week', 'once a month', or 'once every two to three months'. Chronic diseases were classified as respiratory disease, circulatory disease, osteoarthropathy, cerebrovascular disease, ocular disease and meatus disease. Frequency of neighborhood outings was ascertained by the frequency of neighborhood outings of 'less than once a week', 'one to less than three times per week', 'three to less than six times per week', and 'almost every day'. The responses were divided into two groups namely 'neighborhood outings less than three times a week' and 'neighborhood outings more than three times a week.' In addition, 'neighborhood' is defined as 'within 800 meter of home' based on a prior study. ${ }^{16}$ Physical ability was assessed by the 'timed up and go test' (TUG), which is associated with the risk of falling. ${ }^{17}$ Psychological ability was ascertained by asking 'do you feel depressed?' with possible answers 'yes' or 'no'. Cognitive ability was assessed as self-reported forgetfulness with possible answers 'yes' or 'no'.

First, this study calculated the student's t-test or chisquare test to examine significant differences between the 'MNE less than 120 USD' group and 'MNE more than 120 USD' group to conduct logistic regression models. Second, logistic regression was conducted to examine the association between MNE and predictor variables. The odds ratio (OR) and 95\% confidence interval (95\% CI) were calculated for MNE. All statistical analysis were performed using IBM SPSS statistical software ver. 23 (IBM Corp.). The study protocol was approved by the ethics committee of Tsubasa Rehabilitation Center on October $30^{\text {th }}, 2014$.

\section{Results}

Basic characteristics of 83 respondents were a total of 39 respondents $(47.0 \%)$ reported MNE of less than the national average; the average number of family members living together was $0.89 \pm 1.19$; a total of 35 respondents $(42.2 \%)$ had more than 13 years of formal education; a total of nine respondents $(10.8 \%)$ reported visiting the hospital once a week; 19 respondents $(22.9 \%)$ reported visiting once a month, and 55 respondents $(66.3 \%)$ reported visiting once every two to three months; the average of number of chronic diseases was $1.78 \pm 1.02$; a total of 63 respondents $(75.9 \%)$ had neighborhood outings more than three times per week; the average TUG was $10.35 \pm 3.73$ seconds; a total of 38 respondents 
Table 1. Characteristics

\begin{tabular}{lll}
\hline Variable & Category & n (\%) \\
\hline Age $($ mean \pm SD) & $81.2 \pm 6.3$ years & \\
Gender & Man & $29(34.9)$ \\
& Woman & $54(65.1)$ \\
Mean number of family living together & $0.89 \pm 1.19$ & \\
Frequency of attending hospitals & $\geq 1 /$ week & $9(10.8)$ \\
& $1 /$ month & $19(22.9)$ \\
Mean number of chronic disease & $1 / 2-3$ months & $55(66.3)$ \\
Educational attainment & $1.78 \pm 1.02$ & \\
& $\geq 13$ years & $35(42.2)$ \\
Frequency of neighborhood outings & $<13$ years & $48(57.8)$ \\
& $\geq 3 /$ week & $63(75.9)$ \\
Physical ability (mean TUG) & $<3 /$ week & $20(24.1)$ \\
Psychological ability & $10.35 \pm 3.73$ & \\
& Depression & \\
Cognitive ability & No & $38(45.8)$ \\
& Yes & $45(54.2)$ \\
& Forgetfulness & \\
& No & $27(32.5)$ \\
& Yes & $56(67.5)$ \\
\hline
\end{tabular}

Table 2. Univariate Associations Between "MNE Less Than 120 USD" Group and "MNE More Than 120 USD" group

\begin{tabular}{ll}
\hline Factor & p value \\
\hline Age & $0.40^{* *}$ \\
Gender & $0.43^{* *}$ \\
Number of family live together & $0.04^{* *}$ \\
Frequency of attending hospitals & $0.04^{* * *}$ \\
Number of chronic disease & $0.03^{* *}$ \\
Educational attainment & $0.02^{* * *}$ \\
Frequency of neighborhood outings & $<0.01^{* *}$ \\
Physical ability (TUG) & $0.30^{* * *}$ \\
Psychological ability & $0.47^{* * *}$ \\
Cognitive ability & $0.27^{* *}$ \\
\hline
\end{tabular}

*: Unpaired t-test, ${ }^{* *}$ : Chi-square test

Table 3. Multivariate Adjusted for OR and 95\% CI for The Association of MNE

\begin{tabular}{|c|c|c|c|c|}
\hline \multirow{2}{*}{ Variable } & \multicolumn{2}{|c|}{ Model 1} & \multicolumn{2}{|c|}{ Model 2} \\
\hline & OR & $(95 \% \mathrm{CI})$ & OR & $(95 \% \mathrm{CI})$ \\
\hline Age & 1.01 & $(0.94-1.90)$ & 1.02 & $(0.94-1.11)$ \\
\hline Gender & 0.52 & $(0.16-1.71)$ & 0.47 & $(0.13-1.71)$ \\
\hline Educational attainment & 0.38 & $(0.13-0.95)^{*}$ & 0.27 & $(0.09-0.84)^{* * *}$ \\
\hline Frequency of neighborhood outings & 3.00 & $(1.02-9.20)^{* * *}$ & 3.23 & $(1.03-10.42)^{* * *}$ \\
\hline Psychological ability & 0.52 & $(0.18-1.47)$ & 0.41 & $(0.14-1.23)$ \\
\hline Cognitive ability & 1.39 & $(0.49-3.91)$ & 1.58 & $(0.53-4.74)$ \\
\hline Physical ability & 1.02 & $(0.89-1.16)$ & 1.00 & $(0.87-1.16)$ \\
\hline Number of family living together & & & 1.49 & $(0.96-2.34)$ \\
\hline Frequency of attending hospitals & & & 0.56 & $(0.21-1.46)$ \\
\hline Number of chronic disease & & & 0.58 & $(0.33-1.05)$ \\
\hline
\end{tabular}

Model 1: Adjusted for age, gender and educational attainment. HosmerLemeshow test: 0.76

Model 2: Adjusted for age, gender, educational attainment, number of family live together, frequency of attending hospitals and number of chronic disease. Hosmer-Lemeshow test: 0.92

*: $<0.05 * *:<0.01$

$(45.8 \%)$ were psychologically healthy; a total of 27 respondents $(32.5 \%)$ were cognitively healthy (Table 1$)$.

As listed in Table 2, educational attainment, chronic disease status, hospital attendance rate, household members and frequency of neighborhood outings were significantly different between the 'MNE less than 120 USD' group and 'MNE more than 120 USD' group ( $\mathrm{p}$ value $=$ $0.02,0.03,0.04,0.04$ and 0.002 respectively). Two logistic regression models were then constructed. In Model 1 , age, gender, educational attainment, frequency of neighborhood outings, physical ability, psychological ability and cognitive ability were added as predictor variables. In Model 2, household members, hospital attendance rate and chronic disease status were added to Model 1 as covariates. This multivariate analysis revealed the following results. In both models, the frequency of outings and educational attainment were significantly different from other predictor variables (Table 3). On Model 1, frequency of neighborhood outings $\mathrm{OR}=3.00$ and $95 \% \mathrm{CI}=1.02-9.20$; educational attainment: $\mathrm{OR}$ $=0.38$ and $95 \% \mathrm{CI}=0.13-0.95$. On Model 2, frequency of neighborhood outings $\mathrm{OR}=3.23$ and $95 \% \mathrm{CI}=$ $1.03-10.42$; educational attainment $\mathrm{OR}=0.27$ and $95 \% \mathrm{CI}=0.09-0.84$.

\section{Discussion}

There were two findings based on this study. First, those who had outings more than three times a week were approximately three times less likely to reduce MNE than those who had outings less than three times a week despite controlling for three covariates. Second, those with more than 13 years of education were approximately four times more likely to increase MNE than those with less than 13 years of education despite controlling for three covariates. Prior studies showed an association between the increasing need of care and MNE. ${ }^{9}$ Moreover, some studies clarified that the homebound status in older adults was a risk factor associated with an increasing need of care and signaled the need for long-term care. Further, limited social participation in older adults was associated with the frequency of outings. ${ }^{18-23}$ Those previous studies hypothesized that improving the frequency of outings would contribute to health awareness and directly or indirectly reduce MNE.

Conversely, in this study, higher educational attainment was significantly associated with increased MNE. Previous studies, which had shown that socioeconomic indicators, such as educational attainment and income, were associated with health status. These studies indirectly showed association between educational attainment and income. Moreover, higher educational attainment is related to higher health literacy while lower educational attainment is related to lower health literacy. ${ }^{24-}$ ${ }^{26}$ Hence, this study hypothesized that MNE for respondents with higher educational attainment increased due to their higher health literacy. However, due to overmedication issues in Japan, it is essential to improve health li- 
teracy appropriately. A previous study reported that both 'high-risk' and 'population-based' approaches were valid approaches for improving health literacy, although there was no consensus in the need to focus on cost-effectiveness. ${ }^{27}$

This study had several limitations. First, due to the small sample size, the results cannot be generalized to all community-dwelling older people. According to previous studies, MNE was associated with age and gender despite no significant difference found in this study. ${ }^{12-13}$ Hence, a larger sample size may better distinguish the factors associated with MNE. Moreover, this study could not clarify an association between those who had not enrolled in any disability prevention programs and those who did enroll. A previous study observed a tendency of higher MNE for non-participating older individuals. ${ }^{9}$ Hence, if more non-participating respondents were recruited, then such factors associated with MNE may be observed and the OR may be lower in the frequency of outings and higher in the educational attainment. Therefore, the results of this study must be viewed with this limitation. Second, despite the fact that environmental factors, such as population density may contribute to MNE, these were not considered in this study. ${ }^{28-29}$ Because the region investigated was an urban area of Tokyo and not a typical district, the results of this study may not apply in other regions or to rural areas. Further investigation is required on this issue. Although further consideration will be needed, this study is significant because frequency of outings and educational attainment are the factors associated with health promotion and reduce MNE.

\section{Conclusion}

In conclusion, this study demonstrated that disability prevention program to maintain outing activities more than three times per week and improve health literacy for older adults is likely to be cost-effective. Although a previous study recommended increasing outings to more than once a week in the aim of maintaining physical health, this study recommends increasing it to more than three times a week for better economic health. ${ }^{30}$ Further, adequate health literacy is essential regardless of the educational attainment of older adults in order to promote health and quality of life in older population. Future study should include demonstrating CUA with larger sample size and different subject characteristics, such as moderately disabled and frail subjects. Findings if this study may help clinicians, community organizations as well as policy makers to select appropriate and effective disability prevention programs.

\section{References}

1. Husereau D, Drummond M, Petrou S, Carswell C, Moher D, Greenberg
D, et al. Consolidated health economic evaluation reporting standards (CHEERS)- explanation and elaboration: a report of the ISPOR health economic evaluation publication guidelines good reporting task force. Value Health. 2013; 16: 231-50.

2. Campbell F, Holmes M, Everson HE, Davis S, Woods HB, Anokye N, et al. A systematic review and economic evaluation of exercise referral schemes in primary care: a short report. Health Technology Assessment [serial on the internet]. 2015 [cited 2015 Oct 31]; 19 [1-110]. Available from:http://www.journalslibrary.nihr.ac.uk/_data/assets/pdf_file/0011 /149609/FullReport-hta19600.pdf

3. Tanajewski L, Franklin M, Gkountouras G, Berdunov V, Edmans J, Conroy S, et al. Cost-effectiveness of a specialist geriatric medical intervention for frail older people discharged from acute medical unit: economic evaluation in a two-centre randomised controlled trial (AMIGOS). PLoS ONE [serial on the Internet]. 2015 [cited 2015 Oct 31]; 10 [1-18]. Available from: http://www.ncbi.nlm.nih.gov/pmc/articles/ PMC4420253/pdf/pone.0121340.pdf

4. Bettschneider C, Luck T, Fleischer S, Roling G, Beutner K, Luppa M, et al. Cost-utility analysis of a preventive home visit program for older adults in Germany. BMC Health Services Research [serial on the Internet]. 2015 [cited 2015 Oct 31]; 15 [1-11]. Available from: http://www.ncbi.nlm.nih.gov/pmc/articles/PMC4392621/pdf/12913_2 015_Article_817.pdf

5. Basu R, Ory MG, Towne SD Jr, Smith ML, Hochhalter AK, Ahn S. Costeffectiveness of the chronic disease self-management program: implications for community-based organizations. Frontiers in Public Health [serial on the Internet]. 2015 [cited 2015 Oct 31]; 3 [1-8]. Available from: http://www.ncbi.nlm.nih.gov/pmc/articles/PMC4410335/pdf/fpubh03-00027.pdf

6. McLean K, Day L, Dalton A. Economic evaluation of a group-based exercise program for falls prevention among the older community-dwelling population. BMC Geriatrics [serial on the Internet], 2015 [cited 2015 Oct 31]; 15 [1-11]. Available from: http://www.ncbi.nlm.nih.gov/ pmc/articles/PMC4404560/pdf/12877_2015_Article_28.pdf

7. Rose G. Sick individuals and sick populations. International Journal of Epidemiology. 2001; 30: 427-32.

8. Ukawa S, Tamakoshi A, Sakamoto A. A systematic review of intervention programs for frail elderly people enrolled in the Japanese social long-term care insurance system. Journal of Japanese Public Health. 2015; 62: 3-19.

9. Yoshida H, Fujiwara Y, Amano H, Kumagai S, Watanabe N, Sangyoon $\mathrm{L}$, et al. Economic evaluation of disability prevention programs for community-dwelling elderly secular trend analyses of medical and care expenses comparing participants and non-participants in the programs. Journal of Japanese Public Health. 2006; 54: 156-67.

10. Carande-Kulis V, Stevens JA, Florence CS, Beattie BL, Arias I. A costbenefit analysis of three older adult fall prevention interventions. Journal of Safety Research. 2015: 52; 65-70.

11. Japanese Statistics Bureau [homepage on the Internet]. Household expenses in older age [updated 2014 Sep 14; cited 2015 June 15]. Available from: http://www.stat.go.jp/data/topics/topi845.htm.

12. Anderson WL, Armour BS, Finkelstein EA, Wiener JM. Estimates of state-level health-care expenditures associated with disability. Healthcare Expenditures and disability. 2010; 125: 44-51. 
13. Hoshi T, Inoue N, Yuasa M, Fujiwara Y, Takagi C, Takahashi T, et al. Socio-economic, subjective health, and lifestyle factors affect future equivalent income (3 years later) of elderly urban-community dwellersA pass analysis. Japanese Journal of Health Education and Promotion. 2013; 21: 3-12.

14. Tirado PO, Tamiya N, Kashiwagi M, Kashiwagi K. Predictors of the highest long-term care expenditures in Japan. BMC Health Services Research [serial on the Internet]. 2011 [cited 2015 Oct 31]; 11: 1-13. Available from: http://www.ncbi.nlm.nih.gov/pmc/articles/ PMC3119177/pdf/1472-6963-11-103.pdf

15. Haun JN, Patel NR, French DD, Campbell RR, Bradham DD, Lapcevic WA. Association between health literacy and medical care costs in an integrated healthcare system: a regional population based study. BMC Health Services Research [serial on the Internet]. 2015 [cited 2015 Oct 31]; 15: 1-11. Available from: http://www.ncbi.nlm.nih.gov/pmc/articles/PMC4482196/pdf/12913_2015_Article_887.pdf

16. Baker PS, Bodner EV, Allmanet RM. Measuring life-space mobility in community-during older adults. Journal of the American Geriatrics Society. 2003; 51: 1610-4.

17. Shumway-Cook A, Brauer S, Woollacott M. Predicting the probability for falls in community-dwelling older adults using the timed up \& go test. Journal of Physical Therapy Science. 2000; 80: 896-903.

18. Konagaya Y, Watanabe T. Evaluation of multimodal factors for the certification of long-term care insurance among community-based elderly: A four-year follow-up study. Nippon Ronen Igaku Zasshi. 2014; 51: 170-7.

19. Imuta H, Yasumura S, Abe H, Fukao A. The prevalence and psychosocial characteristics of frail elderly in Japan: a community-based study. Aging Clinical and Experimental Research. 2001; 13: 443-53.

20. Imuta H, Yasumura S, Ahiko T, Fukao A. Predictors of functional status among independent and homebound community dwelling elderly: Physical, psychological, and social parameters. Japanese Journal of Public Health. 2002; 49: 483-96.

21. Hirai H, Kondo K, Ojima T, Murata C. Examination of risk factors for onset of certification of long-term care insurance in community-dwelling older people: AGES project 3-year follow-up study. Japanese Journal of Public Health. 2009; 56: 501-12.
22. Takeda T, Kondo K, Hirai H. Psychosocial risk factors involved in progressive dementia-associated senility among the elderly residing at home: AGES project-three year cohort longitudinal study. Japanese Journal of Public Health. 2010; 57: 1054-65.

23. Shinkai S, Kumagai S, Fujiwara Y, Amano H, Yoshida Y, Watanabe S, et al. Predictors for the onset of functional decline among initially nondisabled older people living in a community during a 6-year follow-up. Geriatrics \& Gerontology International. 2003; 3: 31-9.

24. Davey J, Holden GA, Smith BJ. The correlates of chronic disease-related health literacy and its components among men: a systematic review. BMC Public Health [serial on the Internet]. 2015 [cited 2015 Oct 31]; 15 [1-12]. Available from: http://www.ncbi.nlm.nih.gov/pmc/articles/PMC4482294/pdf/12889_2015_Article_1900.pdf

25. Lee TW, Lee SH, Kim HH, Kang SJ. Effective intervention strategies to improve health outcomes for cardiovascular disease patients with low health literacy skills: a systematic review. Asian Nursing Research. 2012; 6: 128-36.

26. Pignone M, Dewalt DA, Sheridan S, Berkman N, Lohr KN. Interventions to improve health outcomes for patients with low literacy: A systematic review. Journal of General Internal Medicine. 2005; 20: $185-92$.

27. Eichler K, Wieser S, Brugger U. The costs of limited health literacy: a systematic review. International Journal of Public Health. 2009; 54: 31324.

28. Lange A, Prenzler A, Bachmann O, Linder R, Neubauer S, Zeidler J, et al. Regional differences in health care of patients with inflammatory bowel disease in Germany. Health Economic Review [serial on the Internet]. 2015 [cited 2015 Oct 31]; 5: 1-11. Available from: http://www.ncbi.nlm.nih.gov/pmc/articles/PMC4608952/pdf/13561_2 015_Article_67.pdf

29. Bohlken J, Selke GW, Bussche H. Prescription differences of dementia drugs in urban and rural areas in Germany. Psychiatrische Praxis. 2011; 38: 232-6.

30. Shimada H, Ishizaki T, Kato M, Morimoto A, Tamate A, Uchiyama Y, et al. How often and how far do frail elderly people need to go outdoors to maintain functional capacity? Archive of Gerontology and Geriatrics. 2010; 50: 140-6. 